\title{
Could a Harvest-Based Citizen Science Program Be an Effective Contribution to Fisheries Research?
}

\author{
Emily Wilmoth*, Josh Dumke ${ }^{\dagger}$ and Ryan Hueffmeier ${ }^{\ddagger}$
}

\begin{abstract}
We surveyed 105 St. Louis River Estuary (SLRE) ice-anglers near Duluth, MN, USA to quantify their interest in participation in a harvest-based citizen science program. This hypothetical program would allow anglers to participate in the generation of scientific knowledge about their fishery, while still taking their fillets home. It would also provide researchers with specimens, mostly walleye (Sander vitreus), to gather data typically requiring euthanized fish (determining sex prior to spawn, diet studies, otoliths for aging and microchemistry, etc.). Our data suggests that most anglers ( $96 \%$ of in-person responses and $92 \%$ of online responses) would be interested in participating if fish processing stations were located close to their ice-fishing location. The majority of anglers (95\% of in-person responses and $77 \%$ of online responses) indicated that receiving a personalized end-of-season report summarizing the information gained from their fish-harvest contributions would make them more likely to participate. These results imply that the hypothetical program could be successful within the SLRE with the proper selection of locations, advertisement, and plans for sharing information. This study has implications that may be useful for researchers and managers of other fisheries with an ample and engaged angling community. Despite some challenges to this approach, it has the potential to be a legitimate method for acquiring fisheries research materials, and at the same time strengthen anglers' trust of managing institutions.
\end{abstract}

Keywords: recreational anglers; fisheries management; harvest; otolith; research; participation

\begin{abstract}
Introduction
Most fisheries studies require the capture of wild fish to accomplish research goals and attain management objectives. Electrofishing and various netting methods are common catch-and-release techniques managers use to collect data about a fish stock. Typical data collected from individual fish, which are representatives of a larger un-sampled population, may include measurements of length and weight, determination of sex (typically only possible to resolve externally within the spawning season), and collection of scales or spines for age estimates. Some non-lethal strategies can also inform researchers about the diet of managed fish stocks, such as gastric lavage to determine recent forage items, and removal of small tissue samples for stable isotope analysis to determine carbon and nitrogen assimilation over a longer term (Post 2002). However, some non-lethal methods to determine fish age or diet can yield misleading or incomplete data. Klein et al. (2017) found ages determined via spines of largemouth bass (Micropterus salmoides) were less precise and had greater between-reader error than sagittal otoliths (fish ear bones;
\end{abstract}

\footnotetext{
* New Jersey Audubon, US

University of Minnesota Duluth, US

* Boulder Lake Environmental Learning Center, US

Corresponding author: Emily Wilmoth (ewilmoth5@gmail.com)
}

can be acquired only after euthanasia), and Bies and Neal (2016) found a pulsed gastric lavage method did not fully empty stomachs of butterfly peacock bass (Cichla ocellaris). Sometimes there is no alternative but to sacrifice fish to correctly answer research questions, but attempting to make that justification about popular game fish within an engaged angling community often meets understandable resistance. A promising approach for collection of deceased fish for scientific study is to utilize the numerous anglers already present at a body of water who are catching fish recreationally for consumption.

Recreational anglers donating portions of their harvest is essentially a form of citizen science, which is defined as public participation in scientific research (Jordan et al. 2015). In theory, researchers and anglers have common goals for the short term (researcher has access to research materials; angler has access to meal(s) of fish), and the long term (researcher produces results that aid management of the fishery; angler notices improvement in the quality of the fishery or meals derived from it), which means both groups could benefit if research and angling communities worked together. Citizen science programs also have benefits that transcend the immediate outcome of producing data or materials for research. Including anglers in a collaborative process of "co-management," sharing power and responsibilities with the resource users, can lessen the perceived impersonal and bureaucratic role of 
institutions in fisheries management (Jentoft et al. 1998), and successful examples of this can be found around the world (Granek et al. 2008). Citizen science programs can also improve the perception of science in a community, as stated by Eleta et al. (2019): "Citizen science provides research institutions with opportunities to rethink the ways they do science and connect with society to improve their positive social and ecological impact and increase trust in science."

Anglers have long participated in a variety of citizen efforts including the collection of water quality and fish population data (Williams et al. 2016), yet there is relatively little peer-reviewed literature describing fisheries projects that incorporated angler harvest as a method to collect data for science. Citizen scientist contributions to fisheries data collections are typically limited to reporting visual observations of fishes (Chin 2014; Thorson et al. 2014; Edgar et al. 2017), self-reporting recreational catch data (Kovačić and Svensen 2018), locating historical records (Clavero et al. 2017), or watching recorded underwater videos to observe fishes (Aguzzi et al. 2015). At times, resource managers will externally tag fish and release them back into the fishery, and then rely on anglers to report (often with low participation) when and where a tagged fish was caught (Miranda, Brock, and Dorr 2002). Thus, angling communities tend to be asked to observe and report rather than be incorporated to the same level of collaborators who contribute physical research material (i.e., actual fish, or inedible parts of fish after filleting).

There is some evidence that anglers are being included in more hands-on activities in more contemporary scientific investigations. An example is Weltersbach et al. (2018), who used anglers to test catch rates of European eel (Anguilla anguilla) using different hook sizes, and then determined post-release mortality of caught eels. That collaboration benefited researchers because they were able to utilize the angling experience of a community, and the anglers benefited by learning what types of tackle would mitigate the impact of recreational post-release eel mortality. Williams, Holmes, and Pepperell (2015) recruited Australian anglers to collect small tissue samples (fin clips) from recreationally caught-and-released black marlin (Istiompax indica). The number of tissue samples those black marlin anglers collected was adequate for the research team to complete a population genetic analysis of the popular sport fish. In other instances, the angling community is asked to use their knowledge and skill to retrieve and donate specimens for scientific study (Fritsches et al. 2000; Zischke et al. 2013), but it is unclear if those fishes were normally what anglers would keep for personal consumption.

Increasingly, researchers and managers aim to target the fishes that anglers are harvesting for consumption via collection of fish heads or frames (carcass remains with head, tail, and entrails intact after fillets are removed). Anglers participating in fish frame donation programs typically must fillet their fish, put the head or frame in a bag, fill out an information card (which may ask for date and location of their catch), and then leave the frame at an established drop-off location for researchers to pick up at a later date. Several of these programs exist in Australia, including the "Keen Angler Program" operated by the Queensland Department of Agriculture and Fisheries, and the "Send Us Your Skeletons" (SUYS) program operated by the Western Australia Department of Fisheries. These programs ask anglers to voluntarily donate fish frames of certain species to be used by researchers for fisheries stock assessments. SUYS proved to be cost-effective and successful in improving sample sizes and representativeness of fish species used in research (Fairclough et al. 2014), and also involved the local fishing community in citizen science.

Fish frame drop-off programs exist in the United States as well, but these tend to be state-sponsored and difficult to find because they are advertised on individual natural resource department websites only when programs are active. The South Carolina Department of Natural Resources (SCDNR) requested in 2018 that anglers harvesting red snapper (Lutjanus campechanus) drop off whole fish frames in freezers at specific locations so researchers could collect them later to measure length and remove otoliths (the preferred aging structure for these fish) (SCDNR 2019). The Florida Fish and Wildlife Conservation Commission (FFWCC) made a similar call to snook (Centropomus undecimalis) anglers in 2018, but in addition to length and age estimates, the FFWCC also determined sex and sexual maturity of harvested snook from the discarded frames (FFWCC 2019). The North Carolina Department of Environmental Quality (NCDEQ) list fourteen species for which they would like fish frame donations, and they provide anglers with twelve drop-off locations (NCDEQ 2019). New York State Department of Environmental Conservation (NYSDEC) announced to Lake Ontario anglers in 2018 that they wanted the frozen heads of coho salmon (Oncorhynchus kisutch) so researchers could retrieve coded wire tags implanted in the snouts of juvenile fish before they were stocked (NYSDEC 2019). While fish frame drop off programs are relatively prolific in marine fisheries, they are relatively rare among inland freshwater systems of the United States, as the NYSDEC example was the only active program identified in our review.

Thus far, all the objectives of the previously described fish frame or head drop-off programs have been to provide managers with data about the harvested fish stock so they can make educated decisions about seasons, regulations, or stocking that will sustain or improve a popular fishery. Yet others have looked to recreational harvest from the view of human health by testing contaminant loading (Heimstad et al. 2015), or angler perception of contamination (Westphal et al. 2008), from harvested fish. Contamination in fish tissue is of interest among U.S. Great Lakes fisheries. The Great Lakes comprise 5 discrete lakes (Superior, Michigan, Huron, Erie, and Ontario) that are all connected to each other, and the Atlantic Ocean, for commercial shipping via manmade canals and modifications to natural connections. Past industrial practices at harbors and cities along large riverine tributaries of the Great Lakes have left us with 26 designated Areas of Concern (AOC) in U.S. waters of the Great Lakes. Many AOC's still 
have legacy pollutants in sediments that make their way into the organisms living there, resulting in restrictive fish consumption advisories intended to protect human health. Most AOC's are in stages of recovery and support recreational fisheries; therefore, the fish anglers retain from these AOCs could be sources of traditional management data (fish size, age, sexual maturity, etc. at time of harvest) as well as contaminant loading data (e.g., heavy metals and dioxins).

We identified a clear knowledge gap regarding the feasibility of collecting fish frames or tissues from anglers at or near their fishing location from a U.S Great Lakes AOC. One such AOC is the St. Louis River Estuary (SLRE) near Duluth, Minnesota, USA, which is the site of the largest industrial port in the Great Lakes (Varian et al. 2017). The impact of industrial practices in the area have ultimately led to the SLRE being designated Minnesota's only AOC. Despite its AOC status, the SLRE supports an abundant and diverse fishery that anglers access during open water and ice-fishing seasons, with the majority of the harvest comprised of walleye (Sander vitreus), black crappie (Pomoxis nigromaculatus), yellow perch (Perca flavescens), and northern pike (Esox lucius) (Varian et al. 2017).

We know anglers are keeping fish to eat from this AOC, but would this angling community be willing to engage with researchers who want parts of their harvest to answer questions about the fish stock? The purpose of this study was to gauge anglers' interest in participating in a citizen science-based approach to fisheries research. Rather than a drop-off program, we described a collection point staffed by management institution personnel, or researchers, which would require less time and effort from participating anglers than drop-off programs, which typically require participants to fillet their own fish, to fill out relevant information such as date and time of catch, and to travel to a drop-off site. Staffed collection points would also offset the bias of drop-off programs, where only a few very dedicated anglers go through the trouble to participate (Williams, Holmes, and Pepperell 2015; M. Connerton (NYSDEC), personal communication). We theorized that staffed collection points would generate higher participation rates among anglers, as well as samples that are more representative of a larger angling community. Additionally, data such as fishing location, date, and time of catch would likely be more accurate when collected immediately and on site. Our goals were to survey anglers of the SLRE AOC to 1) quantify participation rates in the prospective program, 2) identify incentives that would raise likelihood of participation, and 3) learn whether anglers made decisions about what fish to harvest based on contamination of the AOC, either real or perceived.

\section{Methods}

The SLRE (Figure 1) was selected because there are multiple fisheries research interests, and the SLRE is nestled between two populous cities: Duluth, MN (2010 census $=86,265)$ and Superior, WI $(2010$ census $=27,244)$. The SLRE spans approximately $37 \mathrm{~km}$ from the Fond du Lac dam to Lake Superior, covers an expanse of 11,500 acres, and represents the border between the states of Wisconsin and Minnesota. The angling population consists mostly of regional residents from Minnesota and Wisconsin (Varian et al. 2017). In the open water fishing season of 2015, 118,849 angler-hours were estimated to have occurred in the SLRE. In the ice-fishing season of 2015-2016, fishing pressure in the SLRE was approximately 25,812 angler-hours (Varian et al. 2017).

We used a survey to quantify anglers' opinions and attitudes regarding participation in a hypothetical citizen science program, which we described as anglers bringing

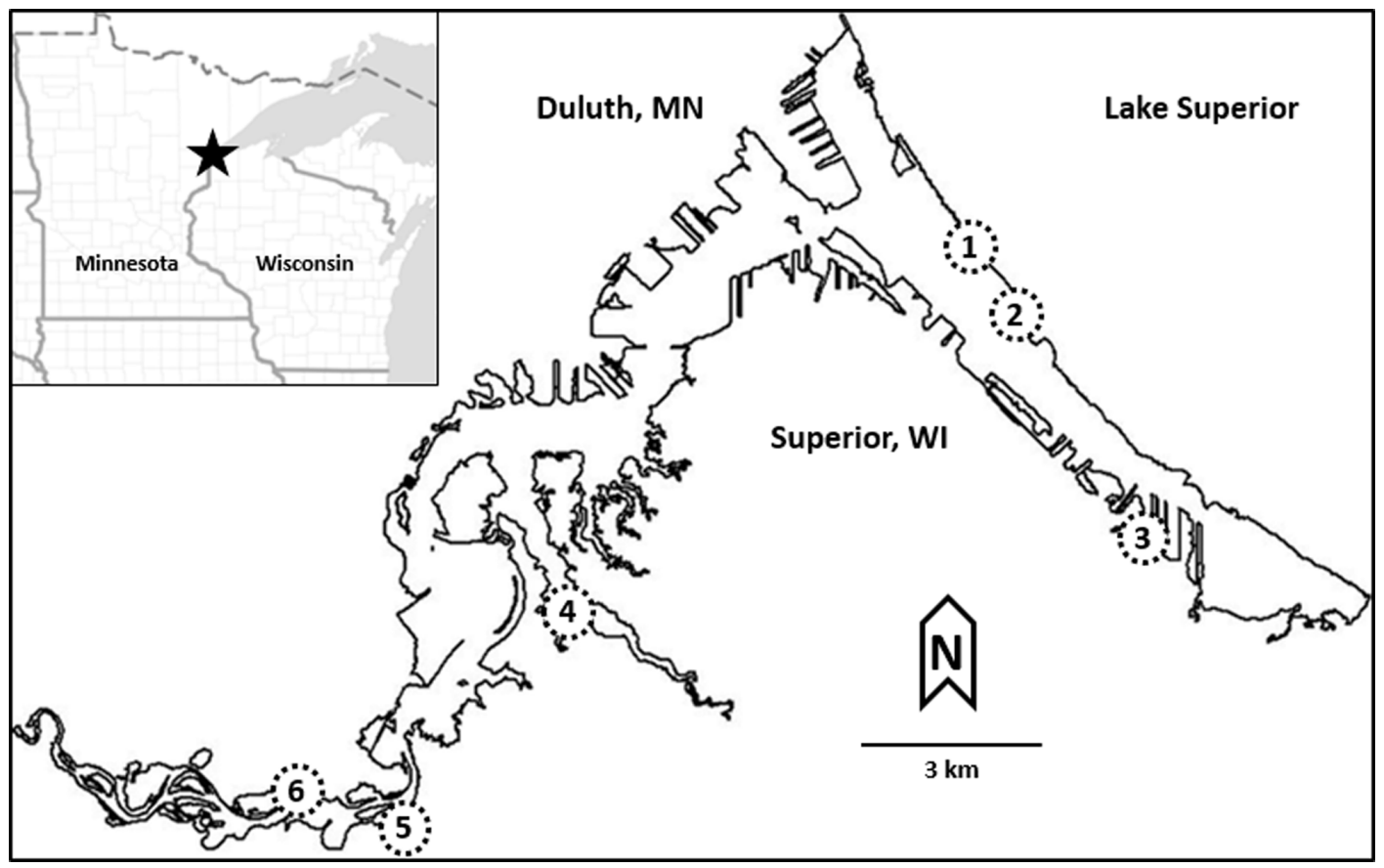

Figure 1: In-person angler survey sites on the SLRE indicated by dashed circles. Sites 1 and 4 are walk-in accesses typically used by anglers only during the ice-fishing season, and the rest are boat accesses used by anglers year round. 
their daily harvest to a staffed collection point for processing, from which they would leave with the fish fillets while we retained the frame. We developed a 13-item survey (Supplemental file 1: Appendix) with specific questions relevant to SLRE anglers, and followed existing guidelines for questionnaire items to enhance internal validity (Dillman et al. 2014). We asked a panel of experts to review the questionnaire to strengthen content, and then we administered a pilot test to determine if any changes needed to be made before data collection began. The University of Minnesota Institutional Review Board reviewed the final survey and determined this project did not meet the regulatory definition of human subject research, and no additional review or approvals were necessary before administering the survey.

The survey was cross-sectional, and data was collected both in person and online. The population studied was ice-anglers of the SLRE. We used nonprobability sampling (Etikan et al. 2015) to select respondents to collect information from the greatest volume of anglers within the relatively short ice-fishing season, as Varian et al. (2017) reported that $65 \%$ of SLRE ice-fishing angling effort occurs in the month of January alone. Purposeful and snowball sampling approaches were used to select in-person and electronic participants, respectively. Purposeful sampling for in-person surveys targeted anglers actively fishing on the ice at locations with specific access points (to concentrate on-and-off-the-ice traffic) and at locations known to be popular ice-fishing spots (accommodating many anglers on any given day), as well as those who were safe and relatively easy for researchers to approach (fishing on safe ice and not too far from the main cluster of anglers). We did not collect any personal or identifiable information from the anglers, and participation was voluntary.

The 13-item questionnaire consisted of mostly yes/no and multiple-choice questions measuring quantitative responses regarding demographics and angler beliefs and opinions about the hypothetical citizen science program. We asked anglers how far they traveled to get to the fishery to determine if local ads, announcements, and postings about the prospective program would reach the target audience. We described a list of potential "extras" so anglers could indicate whether each would positively influence their likelihood of participation. We asked anglers how often they fished and what fish they were attempting to catch to assess the quantity and species of fish they would most likely deliver to processing stations. Finally, we asked anglers why they decided not to harvest certain fish to learn their perceptions about contaminants in fish, and whether education and information about fish contamination (in collaboration with the Minnesota Department of Health) in the SLRE should be incorporated into the processing stations. It took between five and ten minutes to complete the survey in person, and about six minutes for participants to complete the survey online.

In-person surveys were conducted at six different sites (Figure 1) within the SLRE over five weekend days in January and February of 2017. We selected three survey sites (two boat accesses and one wintertime walk-in access) along each shoreline for Wisconsin and Minnesota. Surveyors went to fishing sites for one to three hours in the morning and one to three hours in the evening during what are typically the most popular times to fish in the SLRE. Surveyors approached anglers on the ice to administer the surveys. We provided a brief overview of the hypothetical citizen science program to each angler before asking him or her to participate in the survey, and we told anglers that to participate in the program they would bring their harvested fish to a processing station to be filleted. Anglers would take their fillets home, and we would use the rest of the fish parts for research.

The electronic version of the survey was created using Google Forms. We sent a link to the online survey to known local anglers via email. Many of these anglers, who were contacts of the researchers, work for government agencies or conduct some type of fisheries research themselves. The email included the same background information shared with anglers during in-person surveys, and a request to forward the survey link to their friends who also ice-fish the SLRE. The electronic survey was open for responses from February 20 to March 1, 2017. We sent a reminder email to the original email recipients three days before the deadline. Although all surveys were administered during the ice-fishing season, anglers who also indicated fishing the SLRE in the open water season were asked additional questions to help determine the feasibility of the hypothetical citizen science program during summer months. The additional open water- season questions were similar in nature to the ice-fishing questions.

\section{Results}

A total of 87 in-person interactions with anglers took place. There were 6 rejections to participate in the survey and 2 repeat interactions, leading to 79 ice-fishing anglers completing the in-person surveys. The electronic survey was completed by 26 anglers, so a grand total of 105 SLRE ice-fishing anglers provided responses. We collected basic information about the anglers representing our sample. All but one of the respondents were resident Wisconsin or Minnesota anglers, and half (51\%) lived within 0 to 10 miles of their fishing location on the SLRE. Anglers also provided the frequency of their fishing efforts on the SLRE during the ice-fishing season: $23 \%$ reported fishing once a month, 36\% fished two or three times per month, 15\% fished four or five times per month, and $26 \%$ fished six or more times per month.

When in-person respondents were initially asked about their interest in the hypothetical citizen science program, 95\% expressed that they would be willing to participate. Similarly, $81 \%$ of online respondents indicated their willingness to participate. Those willing to participate further qualified their likelihood of engaging the program in terms of location and convenience: $96 \%$ of in-person respondents indicated that they would participate if the fish processing station was located at the parking area of their fishing location (not including "maybe" responses). This percentage dropped to $75 \%$ if the station was located between their fishing location and home, and 35\% if it was a short drive out of their way. Percentages regarding participation based on location were slightly lower among online respondents, but followed the same trend. (Figure 2).

When provided with a list of potential extra benefits that may be included at fish processing stations, anglers 
indicated which options would positively influence their decision to participate in the hypothetical citizen science program. We asked anglers to indicate the importance of the following six potential extras (anglers could select all that apply): 1) a personalized report displaying how each angler's harvest contributed to research goals, 2) knowledge of an alternative destination (compost) for fish frames to keep them out of landfills, 3) area heaters during cold weather, 4) local information provided about the SLRE and Lake Superior, 5) snacks and/or drinks, and 6) a covered area to wait while fish are being processed. The most commonly selected extra, by both in-person and online respondents at $95 \%$ and $77 \%$, respectively, was the report summarizing the information gained from their fish harvest (Figure 3). A greater percentage of in-person respondents than online respondents selected each of the extras.

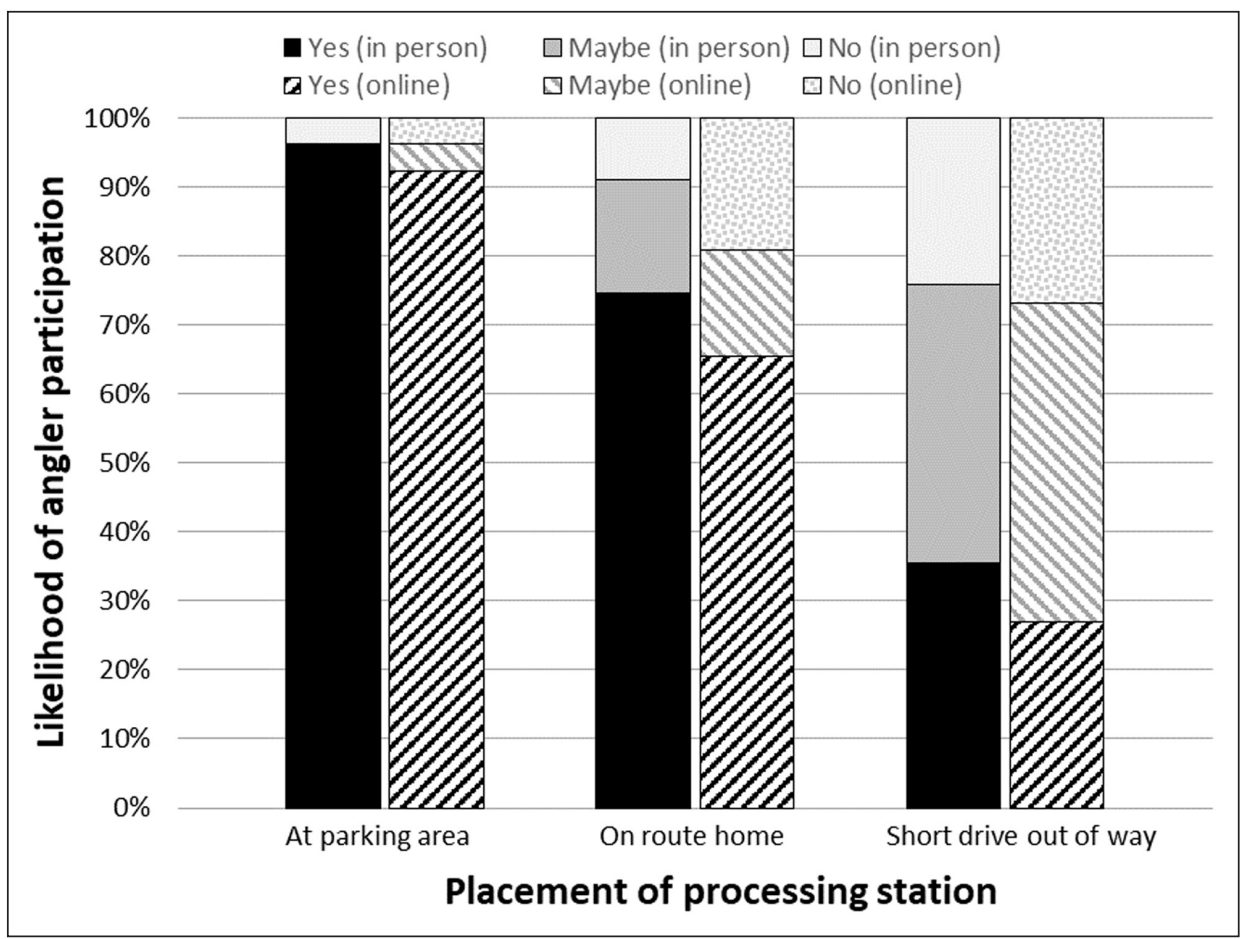

Figure 2: Angler responses on likelihood of participation in hypothetical citizen science program based on potential location of fish processing station(s).

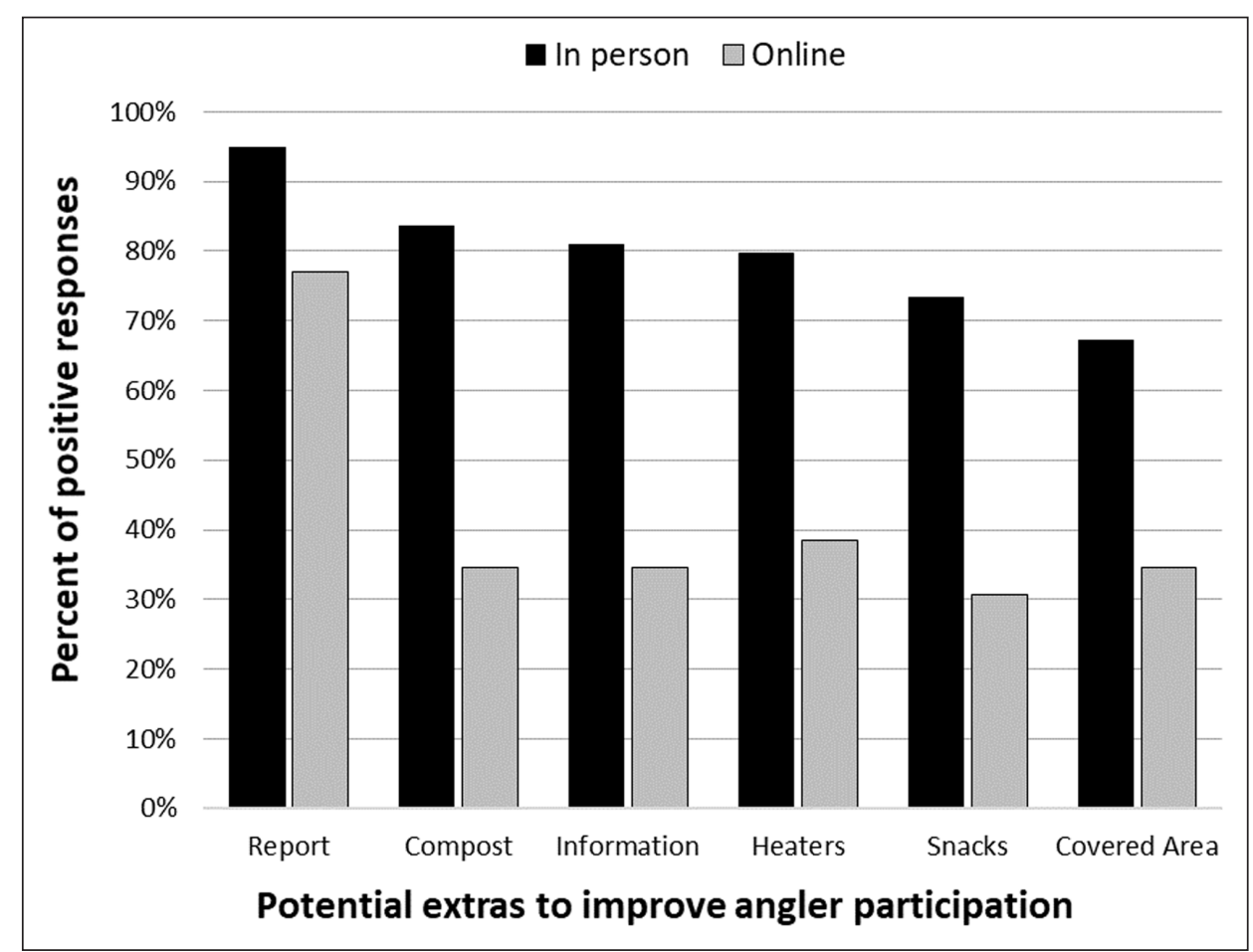

Figure 3: Potential extras influencing likelihood of angler participation in the hypothetical citizen science program. Anglers could select more than one option. 
Anglers indicated they target seven fish species while fishing the SLRE in the winter. Walleye was the most commonly listed target species among all respondents $(\mathrm{n}=76)$, followed by black crappie $(\mathrm{n}=48)$, yellow perch $(\mathrm{n}=11)$, burbot (Lota lota) $(\mathrm{n}=7)$, northern pike $(\mathrm{n}=5)$, bluegill (Lepomis macrochirus) $(\mathrm{n}=5)$, and lake sturgeon (Acipenser fulvescens) $(\mathrm{n}=1)$. The lake sturgeon fishery in the SLRE is catch and release only. Anglers described reasons for releasing certain fish that they catch while ice-fishing the SLRE. Fish being "too small" was the most frequent response (89\%) provided by in-person respondents (Table 1), followed by fish that are "too big" (24\%). Among online respondents, keeping big breeders in the water was the most frequent response (54\%), followed by contamination concerns (35\%). No in-person respondents specifically stated contamination concerns as a reason for releasing fish. However, some of the anglers who indicated releasing fish that were too big may have done so because of contamination concerns that were not verbalized.

Anglers who indicated they also fish the SLRE during the open water season were asked additional questions. Of these 72 anglers, 63 (88\%) said they would be interested in participating in the program in the open water season. Frequency of fishing by anglers in the open water season was similar to frequency in the winter: $17 \%$ fished the SLRE once a month during the summer, 33\% fished two or three times per month, $14 \%$ fished four or five times per month, and 36\% fished six or more times per month. Anglers indicated they target five fish species and two broader taxonomic groups of fishes while fishing the SLRE in the summer. Walleye was the most commonly listed target species among all respondents $(\mathrm{n}=66)$, followed by muskellunge (Esox masquinongy) $(\mathrm{n}=11)$, black crappie $(\mathrm{n}=10)$, northern pike $(\mathrm{n}=10)$, yellow perch $(\mathrm{n}=3)$, trout and salmon (Salmoninae), $(\mathrm{n}=3)$, and black basses (Micropterus spp.) $(\mathrm{n}=1)$. Four anglers responded "anything" when asked about summer target species. Reasons for releasing certain fish in the summer were similar to reasons given in the winter and maintained consistent differences between in-person and online responses.

\section{Discussion}

The demographics of the anglers surveyed in this study are consistent with the creel survey report published by the Minnesota Department of Natural Resources (MNDNR) (Varian et al. 2017), as our data also indicates that the majority of anglers fishing the SLRE are local. We also found that most anglers fish the SLRE more than once a month. This information suggests that because the surveyed anglers showed interest in our hypothetical program, it has the potential to be successful owing to the accessibility of likely repeat participants (assuming participants have a good first experience with the program). Furthermore, the target species indicated by the participants in this study were also similar to the findings of the MNDNR creel (Varian et al. 2017), with walleye being the most sought and harvested fish during ice-fishing or open water seasons. The agreement of our angler survey results with MNDNR creel findings indicate that although our study was smaller (79 interviewed iceanglers in our study versus 457 by MNDNR), our angler responses remain representative of the larger SLRE angling community.

The SLRE fishery is dominated by walleye harvest, yet a variety of other species in the SLRE are also targeted by anglers. Diversity of harvest can potentially support many different goals through a harvest-based research program. For example, the five most recreationally harvested species during the 2015-2016 open water and ice-fishing seasons, respectively, were walleye (9,321 and 1,160), black crappie (907 and 302), yellow perch (102 and 507), northern pike (392 and 59), and channel catfish (479 and 0) (Varian et al. 2017). Angler harvest in the SLRE has been tracked sporadically since 1980 , and although we report the results of the most recent creel survey (2015-2016), prior creel surveys indicate harvest can be much higher. Open water walleye harvest in 2003 was estimated at nearly 43,000 walleye, which was 4.6 times the 2015 walleye harvest, with the same daily bag and size restrictions between the two time periods (Varian et al. 2017). Opting to select fisheries where creel survey data already exists would likely improve the success of a harvest-based fisheries research program, where we measure success as reaching the target sample size for fish species of interest within a given

Table 1: Angler reasons for releasing certain fish caught while ice-fishing the SLRE displayed as percent of surveyed anglers to select each response (based on 79 and 26 individuals from in-person and online surveys, respectively), with sum of each response in parentheses. Anglers could provide more than one response.

\begin{tabular}{lcc} 
Reason for releasing fish & $\begin{array}{c}\text { In-person } \\
\text { responses }\end{array}$ & $\begin{array}{c}\text { Online } \\
\text { responses }\end{array}$ \\
\hline Too small & $89 \%(\mathrm{n}=70)$ & $12 \%(\mathrm{n}=3)$ \\
Too big (no further explanation provided) & $24 \%(\mathrm{n}=19)$ & $8 \%(\mathrm{n}=2)$ \\
Keep big breeders in the water & $13 \%(\mathrm{n}=10)$ & $54 \%(\mathrm{n}=14)$ \\
Regulations (slot, bag limit, etc.) & $11 \%(\mathrm{n}=9)$ & $15 \%(\mathrm{n}=4)$ \\
Catch-and-release fishing & $8 \%(\mathrm{n}=6)$ & $12 \%(\mathrm{n}=3)$ \\
Species (do not eat, cultural beliefs, etc.) & $8 \%(\mathrm{n}=6)$ & $8 \%(\mathrm{n}=2)$ \\
Contamination concerns & $0 \%(\mathrm{n}=0)$ & $35 \%(\mathrm{n}=9)$
\end{tabular}


amount of effort. For example, in the 2015-2016 fishing season, yellow perch harvest was greater during the icefishing season, and channel catfish were harvested only during the open water fishing season (Varian et al. 2017), so the angling season targeted by a harvest-based fisheries research program could be tailored to the fish species of interest to improve likelihood of program success.

This study assessed the interest from a subset of SLRE anglers (specifically ice-anglers) in participating in a hypothetical citizen science program in which they would provide fish frames for research. The majority of anglers expressed interest in participating in the program. However, we found that the location of the fish processing stations could be a major influence on the anglers' likelihood to participate. While $96 \%$ of in-person respondents and $92 \%$ of online respondents indicated that they would participate if the station were placed directly at their fishing access site, percentages dropped to $35 \%$ and $27 \%$ for in-person and online respondents, respectively, if the station were located a short drive out of their way. Placing processing stations as close as possible to fishing locations (i.e., making participation easy) may be critical to the success of the type of program proposed in our study. Success may also depend on whether active (in-person) or passive (drop-off) collection methods are used. New York State Department of Environmental Conservation (NYSDEC) indicated anglers and professional fish cleaners participating in their dropoff program returned about $8 \%(\sim 400)$ of the estimated 4,800 coho salmon harvested in 2018 , but those samples tended to come from a relatively narrow group of individuals (M. Connerton, personal communication). By comparison, when NYSDEC staff targeted popular boat landings, charter fishing docks, and fishing tournaments to interact in-person with anglers harvesting fish they gathered an additional 200 samples with voluntary compliance rates of "over 90 percent" (M. Connerton, personal communication). In this example, the in-person interactions elicited greater participation rates and included anglers who may not have contributed to the drop-off program.

The most appealing extra benefit to our surveyed anglers was the personalized report on their fish. This finding supports citizen science literature that has identified the importance of showing participants the usefulness of their contribution to the scientific process (Dickinson et al. 2012; Land-Zanstra et al. 2016). Providing a fisheries report to anglers could motivate them to participate in the program repeatedly, which would increase retention. Additional extras such as snacks and a covered area to wait while fish are processed proved to be of lesser importance to anglers. While receiving a report was the most frequently selected, $52 \%$ of anglers from in-person surveys selected all of the options, so it is not the only one to consider. Therefore, any extras offered at processing stations could be tailored to the community interests wherever a program like this is considered. It is important to note that $91 \%$ of anglers (average of in-person and online responses) said they would be interested in participating in the program before they became aware of any of the potential extras.
The absence of stated contamination concerns from in-person respondents (general public) versus online respondents (largely comprised of agency or natural resource staff) may indicate a lack of knowledge regarding the SLRE's AOC status among recreational anglers (Table 1). The opportunity exists for anglers to be educated about the fishery's water quality and consumption advisories while they interact with researchers at the processing station. The fact that anglers showed interest in receiving a report of data concerning the fish they donate, as well as local information regarding the SLRE and Lake Superior, suggests that most anglers would be receptive to educational efforts. Smartphone applications (apps) could be a piece of technology to facilitate the interaction between researchers and recreational anglers. As of 2018, 95\% of 18 to 34 year-olds, $90 \%$ of 35 to 49 year-olds, and $60 \%$ of people 50+ owned smartphones in the United States, and those percentages are rising (Pew Research Center 2019). Papenfuss et al. (2015) determined angler movement patterns using a smartphone fishing app, and concluded that apps have the potential to be a relevant mechanism for data collection and a method of disseminating information in our time. Although we did not ask anglers how they would like to receive reports derived from their contributions, we speculate the development of a companion smartphone app would likely make the conveyance of information easy and appealing to contemporary anglers.

The costs for operating an angler citizen science program like our hypothetical depiction are minimal in its most basic form, but would scale accordingly with fish sample sizes desired and angler harvest success rates. Angler responses indicated that investing in a shelter such as a trailer or tent might not be necessary to attract participation. A simple table or vehicle parked at popular access points, with some signage to indicate the presence of the operation, could prove sufficient. Ensuring anglers are aware of the processing location, hours of operation, and its intended purpose would be critical to elicit participation, so advertisement before implementation is recommended (hence the recommendation of developing a smartphone app where anglers can view processing station locations and hours of operation in advance, and receive updates in real time). Williams, Holmes, and Pepperell (2015) went as far as to advertise their genetics project in Australian newspapers, magazines, websites, social media, workshops, and tournaments throughout their two-year project term to target black marlin anglers so they could recruit as many individuals into their program as possible. The time and money spent advertising paid off for Williams, Holmes, and Pepperell (2015), as they attained their stated goals to perform population genetic analysis from angler-contributed tissue samples, and their project was considered a success.

We proposed to anglers that trained scientists would be present at fish processing stations to interact with anglers and to collect data and tissues from harvested fishes. This was proposed intentionally not only to improve participation rates, but also as a way to ensure data integrity and support the use of that data by decision-making bodies, as one of the greatest challenges in citizen science is having 
data viewed as untrustworthy or unusable (Conrad and Hilchey 2011). Having trained scientists perform the data collection also eliminates the need to teach anglers how to collect the data needed so they can focus on the joy of fishing. However, this means that several station workers may need to be present to process the fish in a timely manner, as long wait times could deter anglers from participating. We also realize that fishing effort tends to be clustered around weekends, holidays, and fishing tournaments. In fact, Kornis et al. (2017) stated that salmon harvest was 2.6 times greater during fishing tournaments than on a typical non-tournament day. Scheduling (where and when stations are in operation) and staffing (how many stations and station workers) would need to be scaled appropriately to match the volume of fish harvested by the angling community and to ensure participants have a good (i.e., fast) experience at processing stations. Whether these workers are paid or a small group of trained volunteers would be dependent on the organization running the program, and the level of training required to gather the data or tissues of interest.

There are some potential limitations and complications. Filleting angler harvest may not always be practical depending on individual states' wild game transportation laws, which can differ among waterbodies and species. It should also be noted that processing station staff would need to collect names and mailing addresses (personal information) if individual angler reports are to be distributed by post. Although we implied this during the survey, it was not explicitly stated. However, the need to collect mailing addresses could be mitigated if a companion smartphone app were developed where anglers could access their personalized information with relative privacy. Lastly, owing to the absence of random sampling, it cannot be implied that the surveyed anglers are representative of the entire SLRE angler population, as these surveys occurred only during the ice-fishing season. However, performing this work during the ice-fishing season has the benefit of ensuring that fish are literally kept on ice until they are processed, which may expand the scope of suitable tissues used for research beyond what would be appropriate in the hot summer months.

We do not propose this approach to research specimen collection as an alternative to electrofishing, netting, or other standard methods used by resource managers in fisheries stock assessments. Instead, we consider it an additional method to consider for select types of data collection. Information that can only be determined from deceased specimens could be gathered without killing fish for the sole purpose of research by utilizing the fish that are already being harvested by anglers. Otoliths can be used to more accurately estimate age of large fishes than scales (Stevenson and Campana 1992) or spines (Dembkowski, et al., 2017). Koenigs et al. (2013) concluded that understanding the correct age distribution of fishes could have an important influence on management decisions. Furthermore, microchemistry of otoliths can be studied to better understand life history and habitat use of fishes, as was performed by Carlson et al. (2016) to determine natal origin of walleye in Missouri River reservoirs.
A processing station could be the optimal tool to engage with anglers and to conduct research on the fillet yield among harvested sizes of fish, as Lyons et al. (2017) found that anglers may take home more meals if fewer, but larger, panfish (bluegill, black crappie, and yellow perch) were harvested. Depending on research interests, other data could be collected from the specimens including sex, gut content, and muscle for mercury concentration. We understand that managers already have methods and sampling schedules to answer questions important for managing their fisheries, but a harvest-based approach involving anglers may support new research opportunities that are novel, or are simply not critical enough to management to support justifying the euthanasia of large samples of fish.

We advise investigators planning to use a harvest-based model, such as we described, to become familiar with relevant laws regarding transportation of fish fillets. In Minnesota (USA), for example, a fish may not be cut into more than two fillets. Most species without length regulations must have a minimum one square inch patch of skin with scales intact so species can be determined, while species with length regulations (such as walleye in the SLRE) must be transported with the head and tail intact so they can be measured if legality of the harvest is in question (MNDNR 2018). Transportation regulations may lead to challenges for managers of programs that seek to fillet fish for anglers. One option may be for researchers to acquire a Fish Processing Operation Permit and fulfill the same obligations as professional fish cleaners. Additionally, managers may consider removing just the gills and entrails (aka "gill and gut"), along with the tissues of interest, as an option for fish data collection, which leaves the head and tail intact so anglers can legally transport fish, but reduces some of the messiness anglers would experience when they finish cleaning fish at their home. Managers should keep in mind that delivering a report that summarizes information gathered from angler harvest was identified as a factor that would influence participation. However, the level of fish processing, as well as the amount of personal information gathered from anglers, would influence the type of report that could be generated.

\section{Conclusions}

This study illustrates how one could use citizen science to collect fish specimens for research through anglers who are already fishing a body of water. We found that a correctly designed program could be a feasible strategy to acquire fish data, tissue, and structures for fisheries research from the SLRE. Although this study was specific to the SLRE fishery, our findings have management implications useful to other fisheries considering a similar approach to specimen collection. Investigators could conduct a survey, as the one described in this study, with anglers of a particular fishery to determine the feasibility of angler participation in a harvest-based citizen science program in a different locale. Once evidence of likely success (high rate of expected angler participation, and harvest of the species of interest) is gathered, funding may be more easily secured for program implementation. Furthermore, the extras that may make anglers more likely to participate, 
and participate repeatedly, should be considered during program development and implementation.

Although this interactive approach may require more time and effort from investigators than some similar operations (i.e., anglers dropping off fish frames), it is stronger in several ways. The process of donating specimens immediately and on site at a fishing location would be more convenient for anglers, which could increase participation rates. Additionally, relevant information such as location and date/time of catch would likely be more accurate if acquired immediately than if reported later (perhaps days later) on an information card for a drop-off station. In many instances, this type of program could compliment the efforts of a standard creel census conducted by managing agencies, which is how NYSDEC structured their in-person collection (M. Connerton, personal communication), and the creel and fish processing objectives could support one another with collaboration between management and research staff.

The relationship between researchers and anglers in this citizen science-based approach can be beneficial to both parties. It provides anglers with an opportunity to participate in real science and to contribute to knowledge about their fisheries. However, the project goals, methodology, data analysis, and definition of project success is devised and administered by a research institution or management agency to ensure validity of the science and to keep the citizen scientist involvement enjoyable; both of which are needed for project success (Galbraith et. al. 2016). Research has shown that participation in fisheries management can lead to greater trust in managing institutions among anglers (Gray et al. 2012), which could be critical if research goals require large sample sizes of deceased sport fish. Additionally, through interaction with managers or researchers, anglers may gain knowledge about the status of their fisheries and the fish that they are harvesting. This can be important for strengthening conservation efforts through public awareness. In conclusion, our study illustrated that an angler citizen science program that contributes to fish research could be feasible in the SLRE, and our methods of gathering this information may prove useful for determining potential angler participation in similar programs elsewhere.

\section{Data Availability Statement}

Survey data are available by request from the corresponding author.

\section{Supplementary File}

The supplementary file for this article can be found as follows:

- Appendix. Angler Participaton Survey. DOI: https:// doi.org/10.5334/cstp.301.s1

\section{Ethics and Consent}

Not applicable. Our project and survey were reviewed by The University of Minnesota Institutional Review Board, which determined this project did not meet the regulatory definition of human subject's research and no additional review or approvals were necessary before adminis- tering the survey. All survey participants provided consent before being asked any survey questions.

\section{Acknowledgements}

Thanks to Dr. Julie Ernst for sharing her survey research expertise, to Dr. Mark Zmudy for his insight as both an angler and a scholar, and to Vincent Welder and Thomas Reed for their assistance with data collection.

\section{Funding Information}

Funding for this project was provided by the University of Minnesota Institute on the Environment (project \#MF0022-16).

\section{Competing Interests}

The authors have no competing interests to declare.

\section{Author Contributions}

Emily Wilmoth took the lead role in participant survey implementation, analysis of data, and manuscript writing. Josh Dumke assisted with study design by selecting survey locations and timeframe, and made substantial contributions toward manuscript writing, review, and revision. Ryan Hueffmeier took the lead role in study design, and contributed critical manuscript review and revisions.

\section{References}

Aguzzi, J, Doya, C, Tecchio, S, De Leo, FC, Azzurro, E, Costa, C, Sbragaglia, V, Del Rio, J, Navarro, J, Ruhl, HA, Company, JB, Favali, P, Purser, A, Thomsen, L, and Catalan, IA. 2015. Coastal observatories for monitoring of fish behaviour and their responses to environmental changes. Reviews in Fish Biology and Fisheries, 25: 463-483. DOI: https://doi.org/10.1007/ s11160-015-9387-9

Bies, MJ and Neal, JW. 2016. Comparison of pulsed gastric lavage and acrylic stomach tubes for sampling the diet of Butterfly Peacock Bass. Transactions of the American Fisheries Society, 145: 854-859. DOI: https://doi.org/10.1080/00028487.2016.1167778

Carlson, AK, Fincel, MJ and Graeb, BD. 2016. Otolith microchemistry reveals natal origins of Walleyes in Missouri River reservoirs. North American Journal of Fisheries Management, 36: 341-350. DOI: https://doi. org/10.1080/02755947.2015.1135214

Chin, A. 2014. "Hunting porcupines": citizen scientists contribute new knowledge about rare coral reef species. Pacific Conservation Biology, 20(1): 48-53. DOI: https://doi.org/10.1071/PC140048

Clavero, M, Ninyerola, M, Hermoso, V, Filipe, AF, Pla, M, Villero, D, Brotons, L and Delibes, M. 2017. Historical citizen science to understand and predict climate-driven trout decline. Proceedings of the Royal Society B, 284(1846): 1-7. DOI: https://doi. org/10.1098/rspb.2016.1979

Conrad, CC and Hilchey, KG. 2011. A review of citizen science and community-based environmental monitoring: Issues and opportunities. Environmental Monitoring and Assessment, 176: 273-291. DOI: https://doi.org/10.1007/s10661-010-1582-5 
Dembkowski, DJ, Isermann, DA and Koenigs, RP. 2017. Walleye age estimation using otoliths and dorsal spines: Preparation techniques and sampling guidelines based on sex and total length. Journal of Fish and Wildlife Management, 8: 474-486. DOI: https://doi. org/10.3996/052017-JFWM-038

Dickinson, JL, Shirk, J, Bonter, D, Bonney, R, Crain, RL, Martin, J, Phillips, T and Purcell, K. 2012. The current state of citizen science as a tool for ecological research and public engagement. Frontiers in Ecology and the Environment, 10: 291-297. DOI: https://doi. org/10.1890/110236

Dillman, DA, Smyth, JD and Christian, LM. 2014. Internet, phone, mail, and mixed-mode surveys: The tailored design method. New York: John Wiley $\&$ Sons.

Edgar, GJ, Stuart-Smith, RD, Cooper, A, Jacques, M and Valentine, J. 2017. New opportunites for conservation of handfishes (Family Brachionichthyidae) and other inconspicuous and threatened marine species through citizen science. Biological Conservation, 208: 174-182. DOI: https://doi.org/10.1016/j.biocon.2016.07.028

Eleta, I, Clavell, GG, Highi, V and Balestrini, M. 2019. The promise of participation and decision-making power in citizen science. Citizen Science: Theory and Practice, 4(1): 8, 1-9. DOI: https://doi.org/10.5334/ cstp.171

Etikan, I, Musa, SA and Alkassim, RS. 2015. Comparison of convenience sampling and purposive sampling. American Journal of Theoretical and Applied Statistics, 5(1): 1-4. DOI: https://doi.org/10.11648/j. ajtas.20160501.11

Fairclough, DV, Brown, JI, Carlish, BJ, Crisafulli, BM and Keay, IS. 2014. Breathing life into fisheries stock assessments with citizen science. Scientific Reports, 4: 7249. DOI: https://doi.org/10.1038/srep07249

Florida Fish and Wildlife Conservation Commission (FFWCC). 2019. Snook anglers asked to help with research. Accessed on 4-10-2019. https://myfwc.com/ research/saltwater/fish/snook/anglers-help/.

Fritsches, KA, Partridge, JC, Pettigrew, JC and Marshall, JN. 2000. Colour vision in billfish. Philosophical Transactions of the Royal Society of London, Series B: Biological Sciences, 355: 1253-1256. DOI: https://doi.org/10.1098/rstb.2000.0678

Galbraith, M, Bollard-Breen, B and Towns, DR. 2016. The community-conservation conundrum: Is citizen science the answer? Land, 5(4): 37. DOI: https://doi. org/10.3390/land5040037

Granek, EF, Madin, EMP, Brown, MA, Figueira, WF, Cameron, DS, Hogan, Z, Kristianson, G, de Villiers, P, Williams, JE, Post, JR, Zahn, S and Arlinghaus, R. 2008. Engaging recreational fishers in management and conservation: Global case studies. Conservation Biology, 22(5): 1125-1134. DOI: https://doi.org/10. 1111/j.1523-1739.2008.00977.x

Gray, S, Shwom, R and Jordan, R. 2012. Understanding factors that influence stakeholder trust of natural resource science and institutions. Environmental Man- agement, 49: 663-674. DOI: https://doi.org/10.1007/ s00267-011-9800-7

Heimstad, ES, Grønstøl, G, Hetland, KT, Alarcon, JM, Rylander, C and Mariussen, E. 2015. A survey of dioxin-like contaminants in fish from recreational fishing. Environmental Monitoring and Assessment, 187: 509. DOI: https://doi.org/10.1007/s10661-0154728-7

Jentoft, S, McCay, BJ and Wilson, DC. 1998. Social theory and fisheries co-management. Marine Policy, 22: 423-436. DOI: https://doi.org/10.1016/S0308597X(97)00040-7

Jordan, R, Crall, A, Gray, S, Phillips, T and Mellor, D. 2015. Citizen science as a distinct field of inquiry. BioScience, 65: 208-211. DOI: https://doi.org/10. 1093/biosci/biu 217

Koenigs, RP, Bruch, RM and Kamke, KK. 2013. Impacts of aging error on Walleye management in the Winnebago system. North American Journal of Fisheries Management, 33: 900-908. DOI: https://doi.org/10.1 080/02755947.2013.815667

Kornis, MS, Webster, JL, Lane, AA, Pankow, KW, Mann, K, Cressman, SR and Bronte, CR. 2017. Recovery rates of stocked and wild Chinook salmon in Lake Michigan, 2011-2015. Report \#2017-07, USFWS Green Bay Fish and Wildlife Conservation Office, New Franken, WI.

Kovačić, M and Svensen, R. 2018. The confirmed and continuous northern distribution of Thorogobius ephippiatus (Teleostei: Gobiidae) with the scientific use of recreational fishing data. Journal of Applied Ichthyology, 34: 691-693. DOI: https://doi.org/10. 1111/jai.13584

Klein, ZB, Bonvechio, TF, Bowen, BR and Quist, MC. 2017. Precision and accuracy of age estimates obtained from anal fin spines, dorsal fin spines, and sagittal otoliths for known-age Largemouth Bass. Southeastern Naturalist, 16: 225-234. DOI: https:// doi.org/10.1656/058.016.0209

Land-Zandstra, AM, van Beusekom, MM, Koppeschaar, CE and Van den Broek, JM. 2016. Motivation and learning impact of Dutch flu-trackers. Journal of Science Communication, 15: 1-26. DOI: https://doi. org/10.22323/2.15010204

Lyons, J, Rypel, AL, Hansen, JF and Rowe, DC. 2017. Fillet weight and fillet yield: new metrics for the management of panfish and other consumption-oriented recreational fisheries. North American Journal of Fisheries Management, 37: 550-557. DOI: https://doi. org/10.1080/02755947.2017.1296514

Minnesota Department of Natural Resources (MNDNR). 2018. 2018 Minnesota fishing regulations. St. Paul, Minnesota: Minnesota Department of Natural Resources.

New York State Department of Environmental Conservation (NYSDEC). 2019. Request for assistance with Coho Salmon head collection. Accessed on 4-102019. https://www.dec.ny.gov/outdoor/112942.html.

North Carolina Department of Environmental Quality (NCDEQ). 2019. Carcass collection program. 
Accessed on 4-10-2019. http://portal.ncdenr.org/ $\mathrm{web} / \mathrm{mf} /$ carcass-collection.

Pew Research Center. 2019. Smartphone ownership is growing rapidly around the world, but not always equally. Washington, DC: Pew Research Center. Available: pewglobal.org/2019/02/05/smartphoneownership-is-growing-rapidly-around-the-world-butnot-always-equally/. (February 2019).

Post, DM. 2002. Using stable isotopes to estimate trophic position: Models, methods, and assumptions. Ecology, 83(3): 703-718. DOI: https://doi.org/10.1890/00129658(2002)083[0703:USITET]2.0.CO;2

South Carolina Department of Natural Resources (SCDNR). 2019. Marine - Red Snapper carcass drop off program. Accessed on 4-10-2019. http://www.dnr. sc.gov/marine/carcassdropoff.html.

Stevenson, DK and Campana, S. 1992. Canadian special publication of fisheries and aquatic sciences: Otolith microstructure examination and analysis. Ottawa, Canada: Canada Communication Group.

Thorson, JT, Scheuerell, MD, Semmens, BX and Pattengill-Semmens, CV. 2014. Demographic modeling of citizen science data informs habitat preferences and population dynamics of recovering fishes. Ecology, 95(12): 3251-3258. DOI: https://doi.org/10.1890/132223.1

Varian, A, Hendrickson, D, Olson, $\mathrm{K}$ and Piszczek, P. 2017. Access based creel survey of the open water and winter fishery 2015-2016 and walleye population estimate on the St. Louis River Estuary, St. Louis
County, Minnesota and Douglas County, Wisconsin. Minnesota Department of Natural Resources Completion Report, Job 998.

Weltersbach, MS, Strehlow, HV, Ferter, K, Klefoth, T, de Graff, M and Dorow, M. 2018. Estimating and mitigating post-release mortality of European eel by combining citizen science with a catch-and-release angling experiment. Fisheries Research, 201: 98-108. DOI: https://doi.org/10.1016/j.fishres.2018.01.010

Westphal, LM, Longoni, M, LeBlanc, CL and Wali, A. 2008. Anglers' appraisals of the risks of eating sport-caught fish from industrial areas: lessons from Chicago's Calumet region. Research in Human Ecology, 15(1): 46-62.

Williams, SM, Holmes, BJ and Pepperell, JG. 2015. The novel application of non-lethal citizen science tissue sampling in recreational fisheries. PloS ONE, 10(9): e0135743. DOI: https://doi.org/10.1371/journal.pone. 0135743

Williams, JE, Rummel, S, Lemon, J, Barney, M, Smith, K, Fesenmyer, K and Schoen, J. 2016. Engaging a community of interest in water quality protection: Anglers monitoring wadeable streams. Journal of Soil and Water Conservation, 71: 114A-119A. DOI: https:// doi.org/10.2489/jswc.71.5.114A

Zischke, MT, Farley, JH, Griffiths, SP and Tibbetts, IR. 2013. Reproductive biology of wahoo, Acanthocybium solandri, off eastern Australia. Reviews in Fish Biology and Fisheries, 23: 491-506. DOI: https://doi. org/10.1007/s11160-013-9304-z

\footnotetext{
How to cite this article: Wilmoth, E, Dumke, J and Hueffmeier, R. 2020. Could a Harvest-Based Citizen Science Program Be an Effective Contribution to Fisheries Research? Citizen Science: Theory and Practice, 5(1): 12, pp. 1-11. DOI: https://doi. org/10.5334/cstp.301
}

Submitted: 09 December 2019 Accepted: 20 January $2020 \quad$ Published: 28 April 2020

Copyright: ( $\odot 2020$ The Author(s). This is an open-access article distributed under the terms of the Creative Commons Attribution 4.0 International License (CC-BY 4.0), which permits unrestricted use, distribution, and reproduction in any medium, provided the original author and source are credited. See https://creativecommons.org/licenses/by/4.0/.

$\mathrm{u}[\quad$ Citizen Science: Theory and Practice is a peer-reviewed open access journal published by Ubiquity Press.

OPEN ACCESS $\boldsymbol{\partial}$ 